\title{
Implementasi Model Pembelajaran Reflektif untuk Meningkatkan Kemampuan Pemahaman Mahasiswa Pendidikan Biologi pada Mata Kuliah Strategi Pembelajaran di Program Studi FKIP Universitas Ahmad Dahlan
}

\author{
Nani Aprilia \\ Progam Studi Pendidikan Biologi, FKIP, Universitas Ahmad Dahlan \\ Kampus III, Jl. Prof. Dr. Soepomo, SH, Yogyakarta, 55164 Indonesia \\ surat elektronik: nani_aprilia@yahoo.com
}

\begin{abstract}
ABSTRAK
Penelitian ini bertujuan untuk meningkatkan pemahaman mahasiswa melalui penerapan model pembelajaran reflektif dalam pembelajaran mata kuliah strategi pembelajaran biologi di Program Studi Pendidikan Biologi Universitas Ahmad Dahlan. Selama ini perkuliahan menggunakan presto ( presentasi total), metode ceramah, tanya jawab, dan penugasan ternyata terdapat kelemahan diantaranya mahasiswa bersifat pasif sehingga berdampak pada pemahaman belajar, kurangnya pemahaman mahasiswa akan berdampak pada keterampilan yang mereka miliki pada saat pelaksanaan pembelajaran ketika mengaplikasikan strategi apa yang akan dipakai sehingga sesuai dengan materi dan karakteristik peserta didik. Karena itu diperlukan solusi untuk meningkatkan pemahaman mahasiswa dengan menerapkan model pembelajaran reflektif dalam pembelajaran mata kuliah strategi pembelajaran biologi. Model pembelajaran reflektif (reflective learning) memberikan kesempatan kepada peserta untuk melakukan analisis atau pengalaman individual yang dialami dan memfasilitasi pembelajaran dari pengalaman tersebut. Pembelajaran reflektif juga mendorong peserta didik untuk berpikir kreatif, mempertanyakan sikap dan mendorong kemandirian pembelajar. Pembelajaran reflektif melihat bahwa proses adalah produk dari berpikir dan berpikir adalah produk dari sebuah proses. Penelitian ini merupakan penelitian tindakan kelas yang dilakukan di Program Studi Pendidikan Biologi Universitas Ahmad Dahlan Yogyakarta, dengan empat prosedur penelitian yang di mulai dari 1) perencanaan, tindakan, observasi, dan refleksi. Subjek penelitian ini adalah seluruh mahasiswa peserta kuliah strategi pembelajaran biologi yang berjumlah 45 orang. Data dikumpulkan dengan teknik observasi, catatan guru dan tes.
\end{abstract}

Kata kunci: model pembelajaran reflektif, pemahaman mahasiswa,strategi pembelajaran biologi

\section{Pendahuluan}

Dunia kerja saat ini menuntut sumber daya manusia yang berkualitas, profesional dan memiliki kemampuan diberbagai bidang. Untuk mewujudkan hal tersebut bisa dicapai melalui pendidikan yang baik. Pendidikan merupakan usaha sadar dan terencana untuk mewujutkan suasana belajar dan proses pembelajaran agar peserta didik secara aktif mengembangkan potensi dirinya (Sisdiknas, 2003). Dengan demikian pendidikan yang baik diharapkan dapat mempersiapkan dan mengembangkan sumber daya manusia sesuai dengan tuntutan dunia kerja.

Pendidikan yang baik dapat dilihat dari pembelajaran yang baik. Untuk menyelenggarakan pendidikan yang baik harus mengembangkan dan melaksanakan pembelajaran yang dapat membekali mahasiswa dengan kemampuan-kemampuan agar dapat melaksanakan tugas sebagai pendidik profesional pada jenjang pendidikan apapun. Untuk menjawab tantangan tersebut, pembelajaran yang dilaksankan harus mengarahkan kepada mahasiswa untuk berperoleh pengetahuan dan pengalaman belajar yang nyata. Mata kuliah stategi pembelajaran biologi merupakan mata kuliah yang wajib di ambil oleh mahasiswa pada semeseter empat. Kompetensi yang diharapkan setelah menyelesaikan mata kuliah strategi pembelajaran biologi diharapkan mahasiswa menguasai hakikat dan makna strategi pembelajaran, pendekatan pembelajaran, metode pembelajaran, pemanfaatan media, sumber belajar, serta mahasiswa mampu mengidentifikasi berbagai jenis strategi pembelajaran yang berorientasi pada peserta didik dan mempertimbangkan serta menentukan strategi pembelajaran yang dapat digunakan dalam kegiatan pembelajaran biologi di sekolah. Berdasarkan evaluasi pembelajaran pada perkuliahan semester yang lalu pembelajaran dilaksanakan dengan memilih metode presto (presentasi total) dengan asumsi awal mahasiswa dapat aktif dalam pembelajaran dan sharing informasi. Berdasarkan evaluasi diperoleh pemahaman mahasiswa 
terhadap materi kurang, mahasiswa mengeluhkan pembelajaran membosankan, dan mata kuliah tidak menarik padahal mata kuliah ini mendasari keterampilan mahasiswa untuk menciptakan pembelajaran yang baik. Dari hasil evaluasi tersebut, diperlukan implementasi model pembelajaran yang dapat membangun daya tarik mahasiswa yaitu dengan menerapkan model pembelajaran reflektif.

Model pembelajaran reflektif yang diterapkan bertujuan untuk meningkatkan kemampaun pemahaman mahasiswa sehingga dapat terinternalisasi dalam diri dan dapat di implementasikan dengan baik, dilandasai dasar teori kontruktivisme dan psikologis kognitif. Tujuan tersebut di perkuat oleh Sukmadinata (2004) pendekatan kompetensi, kontektual dan berbasis pengalaman, mencari dan bermakna. Soekamto (Trianto, 20I3) berpendapat bahwa model pembelajaran adalah kerangka konseptual yang melukiskan prosedur yang sistematis dalam mengorganisasikan pengalaman belajar untuk mencapai tujuan belajar tertentu, dabn berfungsi sebagai pedoman bagi para perancang pembelajaran dan para pengajar dalam merencanakan aktifitas belajar mengajar. Senada dengan pendapatnya Suprijono (2009) menyatakan bahwa model pembelajaran saat di artikan sebagi pola yang digunakan untuk peyusunan kurikulum, mengatur materi, dan memberi petunjuk kepada guru di kelas.

Implementasi model pembelajaran reflektif di dasarkan pada asumsi 1) penerapan model pembelajaran berupaya mempertemukan model mengajar pendidik dan model belajar peserta didik (social cognitive perspektives), menekankan pendidik sebagai pengajar dan peneliti (teacher as learner and researcher). 2) didasarkan pada pandangan Ginberg \& Cliff dalam tulisannya di handbook research on teacher education (I990), Dunkin, MJ \& Biddle BJ (I936), dan LaBoskey (1993) yang mengungkapkan bahwa mengajar merupakan praktek reflektif, dan perlunya calon pendidik terlebih dulu belajar melalui pengalaman, dengan cara merenung dan merekontruksikan struktur kognisinya (Ingridwati, 20II). Unsur reflektif tersurat dalam rumpun kompetensi pedagogiek, kepribadian, profesional, dan tersirat dalam rumpun kompetensi sosial sebagai dampak pengiring pembelajaran. Kemampuan reflektif memungkinkan mahasiswa merefleksikan pengalaman mengajar dan mengambil hikmah, sehingga dapat digunakan untuk memperbaiki dan meningkatkan mutu pembelajaran selanjutnya. Model pembelajaran reflektif (reflective learning) memberikan kesempatan kepada peserta untuk melakukan analisis atau pengalaman individual yang dialami dan memfasilitasi pembelajaran dari pengalaman tersebut. Pembelajaran reflektif juga mendorong peserta didik untuk berpikir kreatif, mempertanyakan sikap dan mendorong kemandirian pembelajar. Pembelajaran reflektif melihat bahwa proses adalah produk dari berpikir dan berpikir adalah produk dari sebuah proses (Donald F. Favareau, 2005).
http://gumilarismail.blogspot.com/2013/II/teoriberpikir-reflektif-john-dewey.html. di unduh pada tanggal 10 April 2015 pukul 13.14 WIB.

Model pembelajaran reflektif untuk meningkatkan kemampuan pemahaman dikembangkan berdasarkan pendekatan filosofi konstruktivisme dan psikologis kognitif. Konstruktisme dalam pembelajaran pada hakekatnya merupakan pendekatan dalam pembelajaran yang didasarkan pada pengalaman (experience is the only basis for knowledge and wisdom), yang kemudian di reorganisasi dan direkronstruksikan. Materi pelajaran harus memungkinkan siswa belajar bagaimana caranya belajar (learning how to learn) dalam bentuk studi kasus atau masalah yang perlu dan bermanfaat untuk dicari jalan keluarnya (problem solving learning) melalui proses inkuiri diskoveri. Proses pembelajaran berpusat pada mahasiswa dan keaktifan mahasiswa, dosen berperan sebagai fasilitator/mediator dan motivator yang menstimulasi mahasiswa untuk belajar sesuatu yang bermakna melalui pemahaman. Menurut Purwanto (I997) pemahaman adalah tingkat kemampuan yang mengharapkan siswa mampu memahami arti atau konsep, situasi serta fakta yang diketahuinya. Sementara Mulyasa (2005) menyatakan bahwa pemahaman adalah kedalaman kognitif dan afektif yang dimiliki oleh individu. Selanjutnya Anas Sudijono (1996) mengemukakan bahwa yang dimaksud dengan pemahaman adalah kemampuan seseorang untuk mengerti atau memahami sesuatu setelah sesuatu itu diketahui dan diingat. Dengan kata lain, memahami adalah mengetahui mengetahui tentang sesuatu dan dapat melihatnya dari berbagai segi. Pemahaman merupakan jenjang kemampuan berpikir yang setingkat lebih tinggi dari ingatan dan hafalan.

Menurut Suharsimi Arikunto (2009) pemahaman (comprehension) siswa diminta untuk membuktikan bahwa ia memahami hubungan yang sederhana diantara fakta-fakta atau konsep. Sedangkan menurut Nana Sudjana (2008) pemahaman dapat dibedakan dalam tiga kategori antara lain : (1) tingkat terendah adalah pemahaman terjemahan, mulai dari menerjemahkan dalam arti yang sebenarnya, mengartikan prinsip-prinsip, (2) tingkat kedua adalah pemahaman penafsiran, yaitu menghubungkan bagian-bagian terendah dengan yang diketahui berikutnya, atau menghubungkan dengan kejadian, membedakan yang pokok dengan yang bukan pokok, dan (3) tingkat ketiga merupakan tingkat tertinggi yaitu pemahaman ektrapolasi.

Dalam penelitian ini, model pembelajaran reflektif di kembangkan berdasarkan konsep Zeichner dan Liston (I996) berkenaan dengan konsep "critical reflection" yang terdiri dari tiga tahap/tingkatan yaitu: I) technical level, refleksi dilakukan pada efesiensi aplikasi dan pengetahuan daam bentuk cara/teknik, 2) contectual level, refleksi dilakukan untuk menemukan keterkaiatan antara situasi problematika dengan tindakan yang dikakukan melalaui aplikasi teori sesuai dengan konteksnya, 3) critical thiking, refleksi dilakukan 
berdasarkan pertimbangan kritis, dan nilai-nilai moral/etis. Berdasarkan konsep tersebut langkahlangkah pembelajaran model pembelajaran reflektif sebagai berikut. (Ingridwati, 20II) I) Tahap persiapan, 2) Tahap Reflektif Technical, 3) Tahap Reflektif Kontekstual, 4) Tahap Reflektif Kritikal, 5) Tahap pemantapan.

\section{Metode Penelitian}

Penelitian ini adalah Penelitian Tindakan Kelas (PTK) yang dilaksanakan dalam proses pembelajaran mata kuliah strategi pembelajaran biologi, dengan subjek penelitian adalah seluruh peserta mata kuliah strategi pembelajaran biologi tahun akademik 2015/2016 (45 orang).

Pelaksanaan Penelitian ini dilakukan dalam 3 siklus, setiap siklus terdiri dari empat tahap : a) perencanaan tindakan, b) pelaksanaan Tindakan, c) observasi, d) refleksi dan perencanaan lanjutan. Indikator keberhasilan tindakan pada penelitian ini adalah persentase jumlah mahasiswa yang memperoleh nilai $\geq 70$ pada penilaian kognitif level pemahaman.

Teknik pengumpulan data dalam penelitian ini observasi, catatan lapangan, dan test. Analisis data pada penelitian ini adalah analisis deskriptif kuantitatif.

\section{Hasil dan Pembahasan}

Berdasarkan hasil analisis data untuk mata kualiah strategi pembelajaran biologi diperoleh peningkatan pemahaman mahasiswa melalui model pembelajaran reflektif. Penerapan model reflektif ini diupayakan untuk meningkatkan pemahaman siswa. Pembelajaran dengan menerapkan model pembelajaran reflektif dengan langkah pembelajaran : I) Tahap persiapan, 2) Tahap Reflektif Technical, 3) Tahap Reflektif Kontekstual, 4) Tahap Reflektif Kritikal, 5) Tahap pemantapan.

Pada pembelajaran pada siklus I setelah penerapan model pembelajaran reflektif diperoleh bahwa $57,77 \%$ mahasiswa belum memenuhi indikator capaian yaitu $\leq$ $70 \%$, dan $42,22 \%$ mahasiswa sudah memenuhi indikator capaian yaitu $\geq 70 \%$. Sedangkan pada pembelajaran pada siklus 2 setelah penerapan model pembelajaran reflektif diperoleh $40 \%$ mahasiswa belum memenuhi indikator $\leq 70 \%$, dan $60 \%$ mahasiswa sudah memenuhi indikator capaian yaitu $\geq 70 \%$. Hal ini sesuai dengan pendapat Fink (1999) yang mengemukakan bahwa pemahaman siswa terjadi setelah pemahaman. Berdiskusi dengan diri sendiri adalah proses di mana siswa mulai berpikir secara reflektif mengenai topik yang dipelajari. Pada proses tersebut siswa bertanya pada diri sendiri mengenai apa yang di pikirkan sehingga siswa akan mampu mengkonstruksi pemahaman mereka secara mandiri. Kemudian hasil kegiatan tersebut akan disusun menjadi pengetahuan yang baru pada struktur kognitifnya. Implementasi model reflektif merupakan upaya yang tepat sebagai solusi peningkatan pemahaman mahasiswa. Untuk lebih jelasnya dapat dilihat pada Gamar I berikut.

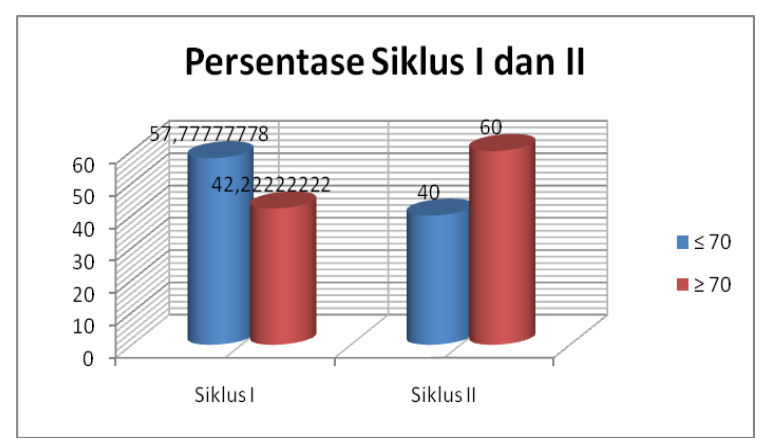

GambarI. Grafik sikuls I dan 2

Analisis data pada siklus I dan siklus 2 diperoleh peningkatan walau tidak begitu signifikan. Pada siklus I ke siklus 2 , mahasiswa yang memperoleh nilai $\geq 70$ meningkat sebesar $17,78 \%$, sedangkan mahasiswa yang memperoleh nilai $\leq 70$ menurun dari siklus I ke siklus 2 sebesar $17,78 \%$.

Berdasarkan temuan tersebut, solusi pendidik untuk mengimplementasikan model pembelajaran reflektif sangat tepat untuk meningkatkan pemahaman mahasiswa yang memiliki cara berpikir yang beragam. Menurut Swindell \& Watson (2006) pada dasarnya kemampuan mahasiswa yang heterogen tersebut dikarenakan cara belajar dan berpikir mahasiswa satu dan yang lain berbeda dari segi pemahamannya. Berdasarkan hal tersebut kegiatan Refleksi perlu dilaksanakan dalam pembelajaran agar mahasiswa mampu mengungkapkan apa yang dialami serta bisa menuliskan apa yang mereka ketahui dan memahami apa yang mereka lakukan.

\section{Simpulan}

Penerapan model pembelajaran reflektif dapat meningkatkan pemahaman mahasiswa dalam mata kuliah strategi pembelajaran biologi. Penerapan model pembelajaran ini meningkatkan pemahaman mahasiswa sebesar $17,78 \%$.

\section{Daftar Pustaka}

Anas Sudijono. 1996. Pengantar Evaluasi Pendidikan. Jakarta: Raja Grafindo Persada.

Arikunto, Suharsimi. 2007. Penelitian Tindakan Kelas. Jakarta : PT Bumi Aksara.

2006. Dasar-Dasar Evaluasi Pendidikan. Jakarta : PT Bumi Aksara

2002. Prosedur Penelitian Suatu Pendekatan Praktek. Jakarta : Rineka Cipta

Fink,D.L.1999. Active Learning, Reprinted with Permission of the Oklahoma Instructional Development Program. Artikel Tersedia pada http://www.edweb.sdsu.edu/people/bdodge/Active/A ctiveLearning.html (diakses tanggal I7 Juli 2016) 
Ingridwati Kurnia. 20II. Pengembangan model pembelajaran untuk meningkatkan kemampuan reflektif mahasiswa PGSD. Tersedia http://www.academia.edu/4889503/Pengembanganmodel-pembelajaran/20II. Di download tanggal 8 April 2015 pukul I4.IOWIB.

Purwanto, M.N. 1997. Prinsip-prinsip dan Teknik Evaluasi Pengajaran Pendidikan. Bandung: Remaja Rosdakarya

Moleong, L. 2002. Penelitian Kualitatif. Jakarta Balai Pustaka

Nana Sudjana.2008. Penilaian Hasil Proses Belajar Mengajar. Bandung: Remaja Rosdakarya.

Sukmadinata. 2004. Kurikulum dan pembelajaran kooperatif. Bandung

Standar Nasional Pendidikan Nomor 20 Tahun 2013.

Sanjaya, Wina. 2009. Strategi Pembelajaran Berorientasi Standar Proses Pendidikan. Jakarta: Kencana Prenada Media Group.

Suharsimi Arikunto. 2009. Dasar - Dasar Evaluasi Pendidikan (edisi revisi). Yogykarta: Bumi Aksara.

Suparijono, Agus. 2009. Coperative learning. Yogyakarta : Pustaka Pelajar

Swindell, ML. \& Watson, J. 2006. Teaching Ethics through Self-Reflective Journaling. Mississippi State University, Journal of Social Work Values and Ethics. 3(2).I-I5

Trianto. 20II. Mendesain Model Pembelajaran InovatifProgresif. Jakarta : Kencana renada Media Group

Wardhani, igak, dkk. 2007. Materi pokok penelitian tindakan kelas. Jakarta: Universitas Terbuka.

Zeichner,K \& Liston,P. 1995. A Handbooks for reflektif teaching : Designed for the new and student teaching. Tersedia http://www.iloveteaching.com//mentor/html 